\title{
USE OF PROBIOTICS FOR FORMATION OF MICROFLORA OF GASTROINTESTINAL TRACT OF CALVES
}

\author{
Oksana Shkromada $\bowtie$ \\ Department of Obstetrics and Surgery ${ }^{1}$ \\ oshkromada@gmail.com \\ Yuliia Dudchenko \\ Department of Obstetrics and Surgery ${ }^{1}$ \\ Yana Udovenko \\ Department of Therapy, Pharmacology, Clinical Diagnostics and Chemistry ${ }^{l}$ \\ ${ }^{1}$ Sumy National Agrarian University \\ 160 Herasyma Kondratieva str., Sumy, Ukraine, 40021
}

$\triangle$ Corresponding author

\begin{abstract}
The results of the use of probiotic strains of microorganisms of the Bacillus family for the correction and formation of the microflora of the gastrointestinal tract and the impact on metabolism in calves are presented.

The aim of the study. To analyze the effect of probiotics on the microflora of the gastrointestinal tract in calves and biochemical parameters of blood in calves up to one month.

Materials and methods. The research was conducted during 2020 in the conditions of Ukrainian farms for cattle breeding. Five experimental groups of five one-week-old calves were formed in each and one control group. Calves were kept separately in the same conditions on the same diet, but with feeding together with colostrum substitute probiotics of five grams per animal: Bacillus amyloliquefaciense, Bacillus mucilaginosus, Bacillus coagulans, Bacillus megaterium, Bacillus pumilus. The strains are deposited and produced by «Kronos Agro» Ukraine.

Results. It was found that as a result of studies when feeding calves B. coagulans, B. pumilus and B. mucilaginosus the number of Lactobacillus sp. was $80 \%$ higher than in the control group. The level of opportunistic pathogens in the experimental group with B. coagulans had minimal values. Animals in the group where B. mucilaginosus was given had a higher amount of Candida - up to $300 \mathrm{CFU/g}$ and Enterobacteriaceae - $200 \mathrm{CFU} / \mathrm{g}$; which is $50 \%$ less compared to control groups, but more than in the experiment with B. coagulans. According to the results of biochemical examination of blood serum in calves, the absence of toxic effects of probiotic strains: Bacillus amyloliquefaciense, Bacillus mucilaginosus, Bacillus coagulans, Bacillus megaterium, Bacillus pumilus on the internal organs of animals was established.

Conclusions. It was found that the maximum positive effect on the microflora of the gastrointestinal tract of calves up to 30 days of age had B. coagulans $\left(1 \times 10^{9}\right)$ when fed at a dose of $5 \mathrm{~g}$ per animal. The amount of Lactobacillus $s p$. was the maximum and reached $800 \mathrm{CFU} / \mathrm{g}$, which is $80 \%$ more than in the control group. At the same time, the level of opportunistic pathogens in the experimental group with B. coagulans had minimal indicators and was: Clostridium by $20 \%$, Escherichia coli - by $70 \%$, Enterobacteriaceae, Staphylococcus and Candida-100\% less than the control.

In the study of biochemical parameters, it was found that the activity of enzymes, protein and glucose levels in the serum of experimental animals fed with $B$. coagulans were within the physiological norm, indicating a normal metabolic process and no toxic effects.
\end{abstract}

Keywords: calves, probiotic strains of Bacillus sp., gastrointestinal microflora, blood biochemical parameters, immunity.

DOI: $10.21303 / 2504-5679.2021 .001951$

\section{Introduction}

Along with the intensive development of livestock breeding methods, breeders' expectations regarding probiotic feed additives are growing, which would guarantee such results as growth acceleration, protection against pathogenic infections and improvement of other production parameters, such as feed digestibility and meat and milk quality [1].

The main reason for the use of probiotics was the desire to achieve certain beneficial effects comparable to the effects of antibiotic-based growth stimulants. The use of probiotics in animal 
nutrition is associated with their proven effectiveness in modulating the intestinal microbiota. The introduction of probiotic strains, both individual and combined, can have a significant impact on the assimilation and use of food, daily weight gain and total body weight of different animals [2]. Used mainly to maintain the balance of the intestinal microbiota of cattle, they are an effective method of combating pathogens that pose a threat to both animals and consumers [3].

The beneficial effect of probiotics in animal husbandry is associated with different modes of action [4]. The improvement in the productivity of all species of animals fed probiotics was mainly due to the fact that probiotics promoted the metabolic processes of digestion and the use of nutrients [5].

The types of used feed additives improve animal health and increase the production of high quality meat, eggs, milk and other products [6]. Animal products are inseparable from the diet and health of the consumer, and intestinal pathogens of animals are a direct source of food contamination and the cause of zoonoses. Therefore, new methods of animal breeding are being introduced, aimed at improving the quality and safety of meat, taking into account animal welfare and respect for the natural environment. Both animal feed and feed additives must meet strict criteria without a simultaneous increase in the cost of breeding animals [7, 8].

Toxic and biochemical studies are necessary to monitor the condition of animals with gastrointestinal diseases [9]. Blood is one of the most important connecting systems of the whole organism. It provides nutrition and respiration of all organs and tissues, supplies them with the necessary enzymes, hormones, mediators and other humoral substances, without which the normal functioning of the body is impossible [10]. In healthy animals under normal physiological conditions there is a stability of chemical and morphological composition and physicochemical properties of blood. Hematopoietic organs are sensitive to the introduction of new substances into the body by changing the blood picture. Therefore, blood tests are of great diagnostic value [11].

In the past, antibiotics and other drugs have been widely used, mainly to modify the alimentary microbiota and increase the productivity and growth of animals [12]. Prolonged use of these substances has led to the development of resistant microorganisms, which threatens the health of consumers and has a negative impact on the environment $[13,14]$. As a result, the use of antibioticbased growth stimulants was banned. Prior to that, they looked for alternative natural substances that provide similar effects [15]. Among such natural substances used in animal nutrition, probiotics are mentioned [16].

Once in the digestive tract, probiotic organisms can survive in difficult conditions and have a beneficial effect on the stability and protection of the intestinal ecosystem. They also affect the course of digestive and metabolic processes and the immunological response [17]. Thus, the properties of probiotics lead to improved animal health, increased productivity and promotes the formation of microflora.

The aim of the study. Analyze the effect of probiotics on the microflora of the gastrointestinal tract and biochemical parameters of blood in calves up to one month.

\section{Materials and methods of the research}

The research was conducted during 2020 in the conditions of Ukrainian farms for cattle breeding. Five experimental groups of five one-week-old calves were formed in each, and one control group was formed. Calves were kept separately in the same conditions on the same diet, but with feeding together with colostrum substitute probiotics $\left(1 \times 10^{9}\right)$ for five grams per animal: Bacillus amyloliquefaciense, Bacillus mucilaginosus, Bacillus coagulans, Bacillus megaterium, Bacillus pumilus. The strains are deposited and produced by «Kronos Agro» Ukraine. The calves had free access to water and hay. Serum samples were taken from the animals after the study.

All animal studies were performed in accordance with Directive 2010/63/EU as amended by Regulation (EU) 2019/1010 and approved by the conclusion of the Commission on Ethics and Bioethics of the Faculty of Veterinary Medicine of Sumy National Agrarian University protocol No. 3 from 21.12.2020.

To study the microflora of the gastrointestinal tract in calves used the bacterial method and determined the composition of microorganisms and their number: Lactobacillus sp., Escherichia 
coli, Enterobacteriaceae, Staphylococcus, Clostridium and Candida. The count of microorganisms was performed after cultivation on elective media, determined the number of colony-forming units in $1 \mathrm{~g}$ of feces (CFU/g).

In order to establish changes in serum biochemical parameters during probiotic feeding, toxic biochemical studies were performed for the presence of possible metabolic changes in calves. The studies were determined by biochemical parameters in serum samples of calves $(n=30)$. Total protein (SOP-BP-02-2017), albumins (SOP-BP-25-2018), total globulins (calculated method), urea (SOP-BP-03-2017), total cholesterol (SOP-BP-07-2017), alanine aminotransferase (ALT) (SOP-BP-09-2017), aspartate aminotransferase (AST) (SOP-BP-08-2017), alkaline phosphatase (ALP) (SOP-BP-04-2017), were measured using an automatic biochemical analyzer using appropriate diagnostic systems [18]. Determined glucose by glucose oxidase method, creatinine using a colorimeter-nephelometer photoelectric PhEC - 56M, Jaffe reaction [19].

Determination of seromucoids in serum samples was performed by the method of Weimer and Moshin [20]; circulating immune complexes (CIC) were performed by the method of Grinevich Y. A., by precipitation with a $3.5 \%$ solution of polyethylene glycol PEG test 280 [21].

The analysis of the studies was performed using Microsoft Excel for Windows 2010. The obtained results in the work were statistically calculated using the Fisher-Student method, taking into account statistical errors and the probability of the indicators being compared. It was considered probable indicators with a level of more than $95 \%(p<0.05)$.

\section{Results}

Raising healthy young cattle is a long and responsible process that will affect their growth and productivity in the future. The development of the gastrointestinal tract in calves, its population by microorganisms can directly affect feed intake, nutrient uptake and overall growth. Even minor changes in the diet and nutrition can affect the development of the formation of the microbiota of the digestive system, which will lead to significant effects on the health and productive qualities of cattle. The results of the study of the effect of probiotics on the microflora of the gastrointestinal tract in calves are shown in Fig. 1.

As a result of the conducted researches it was established that when feeding calves B. coagulans, B. pumilus and B. mucilaginosus the amount of Lactobacillus sp. was the maximum and reached $700-800 \mathrm{CFU} / \mathrm{g}$, which is $80 \%$ more than in the control group. The level of opportunistic pathogens in the experimental group with $B$. coagulans had minimal values and was: Clostridium by $20 \%$, Escherichia coli - by $70 \%$; Enterobacteriaceae, Staphylococcus and Candida - $100 \%$ less than the control. Animals in the group where B. mucilaginosus was given had a higher amount of Candida - up to $300 \mathrm{CFU} / \mathrm{g}$ and Enterobacteriaceae - $200 \mathrm{CFU} / \mathrm{g}$; which is $50 \%$ less compared to control groups, but more than in the experiment with B. coagulans.

B. megaterium did not inhibit the growth of Clostridium and Staphylococcus and Candidaby $10-15 \%$, less than the control.

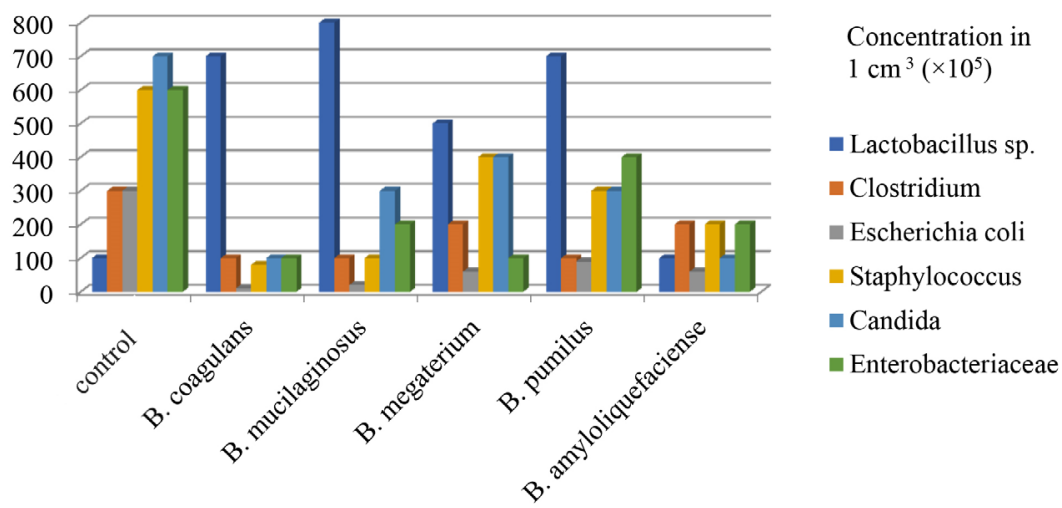

Fig. 1. The effect of probiotics on the formation of the microflora of the gastrointestinal tract in calves 
In the group where B. pumilus was used as a probiotic, the amount of Clostridium, Candida and Enterobacteriaceae did not decrease significantly compared to the control (by $35 \%$ ).

B. amyloliquefaciense did not create favorable conditions for the growth and reproduction of Lactobacillus sp. (up to $100 \mathrm{CFU} / \mathrm{g}$ ). However, the level of Clostridium, Staphylococcus and Enterobacteriaceae did not exceed 200-100 CFU/g.

Based on the results obtained before the use of probiotic strains of Bacillus, it was found that the maximum positive effect on the microflora of the gastrointestinal tract of calves up to 30 days of age had B. coagulans.

To clarify the results and establish the possible toxic effects on the body of calves, a biochemical study of blood serum was performed at the end of the study (30 days).

The results of biochemical studies of blood sera of calves are summarized in Table 1.

Table 1

The level of basic biochemical parameters in the serum of young cattle $(n=5)$

\begin{tabular}{|c|c|c|c|c|c|c|c|}
\hline \multirow[b]{2}{*}{ Indicators } & \multicolumn{5}{|c|}{ Experimental groups in which probiotics were used: } & \multirow[b]{2}{*}{ Control } & \multirow{2}{*}{$\begin{array}{l}\text { Refe- } \\
\text { rence } \\
\text { level }\end{array}$} \\
\hline & $\begin{array}{l}\text { B. coagu- } \\
\text { lans }\end{array}$ & $\begin{array}{l}\text { B. mucilag- } \\
\text { inosus }\end{array}$ & $\begin{array}{l}\text { B. megate- } \\
\text { rium }\end{array}$ & $\begin{array}{l}\text { B. pu- } \\
\text { milus }\end{array}$ & $\begin{array}{l}\text { B. amyloli- } \\
\text { quefaciense }\end{array}$ & & \\
\hline Total proteins, g/l & $72.4 \pm 0.32$ & $74.2 \pm 0.22$ & $71.3 \pm 0.25$ & $68.4 \pm 0.31$ & $69.8 \pm 0.22$ & $60.3 \pm 0.23$ & $55.0-76.0$ \\
\hline Albumins, g/l & $34.6 \pm 0.12$ & $33.6 \pm 0.15$ & $33.7 \pm 0.17$ & $30.5 \pm 0.16$ & $31.8 \pm 0.19$ & $29.1 \pm 0.15$ & $25.0-37.5$ \\
\hline Total globulins, g/l & $37.8 \pm 0.23$ & $38.2 \pm 0.14$ & $36.7 \pm 0.22$ & $38.0 \pm 0.33$ & $37.7 \pm 0.20$ & $31.2 \pm 0.22$ & $25.0-38.5$ \\
\hline Urea, mmol/1 & $3.02 \pm 0.18$ & $3.51 \pm 0.22$ & $3.06 \pm 0.34$ & $3.56 \pm 0.15$ & $3.34 \pm 0.22$ & $3.07 \pm 0.18$ & $3.0-6.5$ \\
\hline Total cholesterol, $\mu \mathrm{mol} / 1$ & $2.02 \pm 0.20$ & $3.82 \pm 0.34$ & $3.41 \pm 0.18$ & $3.42 \pm 0.20$ & $3.78 \pm 0.23$ & $3.46 \pm 0.22$ & $1.3-4.0$ \\
\hline Glucose, mmol/1 & $3.38 \pm 0.27$ & $3.21 \pm 0.32$ & $3.08 \pm 0.22$ & $3.62 \pm 0.28$ & $3.55 \pm 0.30$ & $3.13 \pm 0.35$ & $3.0-4.2$ \\
\hline ALT activity, mmol/1 & $0.89 \pm 0.28$ & $0.77 \pm 0.18$ & $0.78 \pm 0.34$ & $0.69 \pm 0.31$ & $0.61 \pm 0.22$ & $0.73 \pm 0.20$ & $0.6-1.8$ \\
\hline AST activity, mmol/year 1 & $1.49 \pm 0.18$ & $1.61 \pm 0.33$ & $1.36 \pm 0.24$ & $1.16 \pm 0.21$ & $1.32 \pm 0.32$ & $1.34 \pm 0.42$ & $0.6-3.0$ \\
\hline Creatinine, $\mu \mathrm{mol} / 1$ & $94.2 \pm 0.24$ & $76.2 \pm 0.22$ & $81.6 \pm 0.19$ & $89.9 \pm 0.21$ & $78.0 \pm 0.12$ & $89.0 \pm 0.22$ & $70-110$ \\
\hline Alkaline phosphatase (ALP) activity, u/l & $149.21 \pm 0.32$ & $187.31 \pm 0.21$ & $177.83 \pm 0.22$ & $178.45 \pm 0.22$ & $165.79 \pm 0.34$ & $172.27 \pm 0.24$ & $100-200$ \\
\hline Circulating immune complexes, $\mathrm{mg} / \mathrm{ml}$ & $0.07 \pm 0.06$ & $0.05 \pm 0.04$ & $0.08 \pm 0.02$ & $0.06 \pm 0.04$ & $0.05 \pm 0.03$ & $0.09 \pm 0.02$ & - \\
\hline Seromucoids, $\mathrm{mg} / \mathrm{ml}$ & $0.13 \pm 0.07$ & $0.17 \pm 0.04$ & $0.14 \pm 0.05$ & $0.18 \pm 0.02$ & $0.14 \pm 0.05$ & $0.18 \pm 0.07$ & - \\
\hline
\end{tabular}

The obtained results give reason to believe that the use of probiotics in calves increased the level of total protein from B. coagulans by $20 \%$; B. mucilaginosus $-22 \%$; B. megaterium by $18 \%$; B. pumilus - by $10 \%$; B. amyloliquefaciense - by $12 \%$ compared to the control group by improving the digestive process. At the same time the level of albumins similarly increases, due to improvement of digestion and assimilation of forages. However, the level of urea in the experimental groups of animals remains within the reference level. Also in the experimental groups the level of globulins from B. coagulans increases by $17 \%$; B. mucilaginosus - $20 \%$; B. megaterium by $18 \%$; B. pumilus - by $20 \%$; B. amyloliquefaciense - by $17 \%$ compared to animals in the control group. This indicates the immunostimulatory effect of probiotics, namely intestinal immunity.

The activity of the enzymes alanine aminotransferase (ALT) and aspartate aminotransferase (AST) was within the physiological norm, which shows the absence of destructive effects of probiotic strains on internal organs and tissues. However, in the experimental groups, alanine aminotransferase is higher by B. coagulans by $21 \%$; B. mucilaginosus and B. megaterium - by $5 \%$; compared with control, as a result of stimulation of metabolic processes in the body.

The level of glucose and total cholesterol in the animals of the experimental and control groups was at the same level and within the physiological norm, which confirms the absence of intoxication from the internal organs. Alkaline phosphatase activity was within physiological limits in both experimental and control animals. It is likely that there was no toxic effect on the liver when feeding probiotics to experimental animals. 
An increase in the number of circulating immune complexes and seromucoids indicates the presence of allergic reactions or chronic inflammatory processes. According to the results of the experiment, it was found that their level is within the physiological norm in all experimental groups of calves.

Creatinine is the end product of protein metabolism in the body. The level of creatinine in the serum of calves indicates the functional state of the kidneys. In this experiment, the creatinine level in the experimental animals is within the reference level.

Summarizing the obtained results of biochemical examination of blood serum in calves, the absence of toxic effects of probiotic strains: Bacillus amyloliquefaciense, Bacillus mucilaginosus, Bacillus coagulans, Bacillus megaterium, Bacillus pumilus on the internal organs of animals was established.

\section{Discussion of research results}

Newborn calves are affected by a number of negative factors such as postpartum stress and changes in temperature. Due to the beginning of scar formation and microflora in young calves, any environmental intervention or changes in nutrition can dramatically affect the development of calves $[22,23]$. Some of the problems include diarrhea and slow weight gain, as well as respiratory diseases, which can lead to high levels of morbidity and mortality and create serious problems for breeding [24].

The species composition, as well as the related functions of the rumen microbiota determine the most important production qualities of ruminants $[25,26]$. The formation of microflora to effectively improve the productive qualities of animals is the goal of many researchers [27, 28]. Dietary supplements (premixes) were used more often, but there were positive and negative results in these experiments. In addition, the microflora in the gastrointestinal tract of calves is not stable enough. Also, to obtain a reliable result, the experiment must be long, which increases the cost of feeding. However, at effective doses, side effects can occur in the form of intoxications, allergic reactions and diarrhea $[29,30]$.

Therefore, the reliability of the results of the experiment was performed for a month and at the end of the experiment determined the species composition of the microflora of the gastrointestinal tract in calves. In addition, to prevent unintended effects on calves of selected probiotic strains of microorganisms Bacillus amyloliquefaciense, Bacillus mucilaginosus, Bacillus coagulans, Bacillus megaterium, Bacillus pumilus determined the level of basic biochemical parameters in the serum.

Biochemical research at the current level of development of industrial livestock is an indispensable component of efficient production. Advanced farms with a high level of profitability conduct periodic biochemical studies of livestock to monitor and correct the condition of the herd.

It is known that the biochemical reactions of substances in the body are closely interrelated. Moreover, metabolic reactions are extremely consistent with each other. Biochemical parameters are a kind of indicator of the processes occurring in the body.

Study limitations. A limitation of the research is the insufficient number of animals involved in the experiment, for a more accurate statistical calculation of the results. However, this study provides a basis for the use of experimental probiotic strains of the family Bacillus in farms for the correction of the microflora in young cattle.

Prospects for further research. The prospect of further research is to determine the effect of probiotics used on calves with severe pathologies of the gastrointestinal tract.

\section{Conclusions}

It was found that the maximum positive effect on the microflora of the gastrointestinal tract of calves up to 30 days of age had B. coagulans $\left(1 \times 10^{9}\right)$ when fed at a dose of $5 \mathrm{~g}$ per animal. The amount of Lactobacillus sp. was the maximum and reached $800 \mathrm{CFU} / \mathrm{g}$, which is $80 \%$ more than in the control group. At the same time, the level of opportunistic pathogens in the experimental group with B. coagulans had minimal indicators of pathogenic microflora and was: Escherichia coli - by 90 \%; Staphylococcus, Enterobacteriaceae and Candida - by 80 \%; Clostridium $60 \%$ less than the control. 
In the study of biochemical parameters, it was found that the activity of enzymes, protein and glucose levels in the serum of experimental animals fed B. coagulans were within the physiological norm, indicating a normal metabolic process and no toxic effects.

\section{Conflict of interests}

The authors declare that they have no conflicts of interest.

\section{Financing}

The research is part of the research work of the Department of Obstetrics and Surgery of Sumy NAU on «Development and improvement of veterinary and sanitary measures to prevent, treat, increase productivity and resistance of animals» (state registration number 0119U101389).

\section{References}

[1] Markowiak, P., Śliżewska, K. (2018). The role of probiotics, prebiotics and synbiotics in animal nutrition. Gut Pathogens, 10 (1). doi: http://doi.org/10.1186/s13099-018-0250-0

[2] Cheng, G., Hao, H., Xie, S., Wang, X., Dai, M., Huang, L., Yuan, Z. (2014). Antibiotic alternatives: the substitution of antibiotics in animal husbandry? Frontiers in Microbiology, 5, 69-83. doi: http://doi.org/10.3389/fmicb.2014.00217

[3] Hao, H., Cheng, G., Iqbal, Z., Ai, X., Hussain, H. I., Huang, L. et. al. (2014). Benefits and risks of antimicrobial use in foodproducing animals. Frontiers in Microbiology, 5. doi: http://doi.org/10.3389/fmicb.2014.00288

[4] Basso, F. C., Adesogan, A. T., Lara, E. C., Rabelo, C. H. S., Berchielli, T. T., Teixeira, I. A. M. A. et. al. (2014). Effects of feeding corn silage inoculated with microbial additives on the ruminal fermentation, microbial protein yield, and growth performance of lambs. Journal of Animal Science, 92 (12), 5640-5650. doi: http://doi.org/10.2527/jas.2014-8258

[5] Tan, J., McKenzie, C., Potamitis, M., Thorburn, A. N., Mackay, C. R., Macia, L. (2014). The Role of Short-Chain Fatty Acids in Health and Disease. Advances in Immunology, 91-119. doi: http://doi.org/10.1016/b978-0-12-800100-4.00003-9

[6] Shkromada, O., Palii, A., Palii, A., Skliar, O., Dudchenko, Y., Necherya, T. (2019). Improvement of milk quality for micro-climate formation on cattle farms. Bulletin of Sumy National Agrarian University. The Series: Veterinary Medicine, 4 (47), 43-49. doi: http://doi.org/10.32845/bsnau.vet.2019.4.7

[7] Kong, L., Yang, C., Dong, L., Diao, Q., Si, B., Ma, J., Tu, Y. (2019). Rumen Fermentation Characteristics in Pre- and Post-Weaning Calves upon Feeding with Mulberry Leaf Flavonoids and Candida tropicalis Individually or in Combination as a Supplement. Animals, 9 (11), 990. doi: http://doi.org/10.3390/ani9110990

[8] Liu, X., Zhao, W., Yu, D., Cheng, J.-G., Luo, Y., Wang, Y. et. al. (2019). Effects of compound probiotics on the weight, immunity performance and fecal microbiota of forest musk deer. Scientific Reports, 9 (1). doi: http://doi.org/10.1038/ s41598-019-55731-5

[9] Rybachuk, Z. V., Shkromada, O. I., Predko, A. V., Dudchenko, Y. A. (2020). Influence of probiotics «Immunobacterin-D» on biocenoses and development of the gastrointestinal tract of calves. Scientific Messenger of LNU of Veterinary Medicine and Biotechnologies, 22 (98), 22-27. doi: http://doi.org/10.32718/nvlvet9804

[10] Ruiz, L., Ruas-Madiedo, P., Gueimonde, M., de los Reyes-Gavilán, C. G., Margolles, A., Sánchez, B. (2011). How do bifidobacteria counteract environmental challenges? Mechanisms involved and physiological consequences. Genes \& Nutrition, 6 (3), 307-318. doi: http://doi.org/10.1007/s12263-010-0207-5

[11] Govender, M., Choonara, Y. E., Kumar, P., du Toit, L. C., van Vuuren, S., Pillay, V. (2013). A Review of the Advancements in Probiotic Delivery: Conventional vs. Non-conventional Formulations for Intestinal Flora Supplementation. AAPS PharmSciTech, 15 (1), 29-43. doi: http://doi.org/10.1208/s12249-013-0027-1

[12] Mingmongkolchai, S., Panbangred, W. (2018). Bacillusprobiotics: an alternative to antibiotics for livestock production. Journal of Applied Microbiology, 124 (6), 1334-1346. doi: http://doi.org/10.1111/jam.13690

[13] Kapse, N. G., Engineer, A. S., Gowdaman, V., Wagh, S., Dhakephalkar, P. K. (2019). Functional annotation of the genome unravels probiotic potential of Bacillus coagulans HS243. Genomics, 111 (4), 921-929. doi: http://doi.org/10.1016/j.ygeno.2018.05.022

[14] Fijan, S. (2014). Microorganisms with Claimed Probiotic Properties: An Overview of Recent Literature. International Journal of Environmental Research and Public Health, 11 (5), 4745-4767. doi: http://doi.org/10.3390/ijerph110504745

[15] Wu, H.-J., Sun, L.-B., Li, C.-B., Li, Z.-Z., Zhang, Z., Wen, X.-B. et. al. (2014). Enhancement of the immune response and protection against Vibrio parahaemolyticus by indigenous probiotic Bacillus strains in mud crab (Scylla paramamosain). Fish \& Shellfish Immunology, 41 (2), 156-162. doi: http://doi.org/10.1016/j.fsi.2014.08.027

[16] Guidance on the assessment of the toxigenic potential of Bacillus species used in animal nutrition (2014). EFSA Journal, 12 (5). doi: http://doi.org/10.2903/j.efsa.2014.3665 
[17] Zhou, Y., Zeng, Z., Xu, Y., Ying, J., Wang, B., Majeed, M. et. al. (2020). Application of Bacillus coagulans in Animal Husbandry and Its Underlying Mechanisms. Animals, 10 (3), 454. doi: http://doi.org/10.3390/ani10030454

[18] Vlizlo, V. V. (2012). Laboratorni metody doslidzhen u biolohii, tvarynnytstvi ta veterynarnii medytsyni. Lviv, SPOLOM, 764.

[19] Levchenko, V. I. Vlizlo, V. V., Kondrakhin, I. P., Holovakha, V. I., Morozenko, D. V., Sakhniuk, V. V. et. al. (2017). Klinichna diahnostyka vnutrishnikh khvorob tvaryn. Bila Tserkva, 544.

[20] Asatiani, V. S. (1957). Biokhimicheskaya fotometriya. Moscow: AN SSSR, 835.

[21] Menshikov, V. V. (1987) Laboratornye metody issledovaniya v klinike. Moscow: Meditsina, 368.

[22] Izuddin, W. I., Humam, A. M., Loh, T. C., Foo, H. L., Samsudin, A. A. (2020). Dietary Postbiotic Lactobacillus plantarum Improves Serum and Ruminal Antioxidant Activity and Upregulates Hepatic Antioxidant Enzymes and Ruminal Barrier Function in Post-Weaning Lambs. Antioxidants, 9 (3), 250. doi: http://doi.org/10.3390/antiox9030250

[23] Da Silva, L. D., Pereira, O. G., da Silva, T. C., Valadares Filho, S. C., Ribeiro, K. G. (2016). Effects of silage crop and dietary crude protein levels on digestibility, ruminal fermentation, nitrogen use efficiency, and performance of finishing beef cattle. Animal Feed Science and Technology, 220, 22-33. doi: http://doi.org/10.1016/j.anifeedsci.2016.07.008

[24] Soares, M. S. P., Oliveira, P. S., Debom, G. N., da Silveira Mattos, B., Polachini, C. R., Baldissarelli, J. et. al. (2016). Chronic administration of methionine and/or methionine sulfoxide alters oxidative stress parameters and ALA-D activity in liver and kidney of young rats. Amino Acids, 49 (1), 129-138. doi: http://doi.org/10.1007/s00726-016-2340-y

[25] Fan, P., Li, L., Rezaei, A., Eslamfam, S., Che, D., Ma, X. (2015). Metabolites of Dietary Protein and Peptides by Intestinal Microbes and their Impacts on Gut. Current Protein \& Peptide Science, 16 (7), 646-654. doi: http://doi.org/10.2174/ 1389203716666150630133657

[26] Aikman, P. C., Henning, P. H., Humphries, D. J., Horn, C. H. (2011). Rumen pH and fermentation characteristics in dairy cows supplemented with Megasphaera elsdenii NCIMB 41125 in early lactation. Journal of Dairy Science, 94 (6), $2840-2849$. doi: http://doi.org/10.3168/jds.2010-3783

[27] Stover, P. J., Durga, J., Field, M. S. (2017). Folate nutrition and blood-brain barrier dysfunction. Current Opinion in Biotechnology, 44, 146-152. doi: http://doi.org/10.1016/j.copbio.2017.01.006

[28] Diao, Q., Zhang, R., Tu, Y. (2017). Current research progresses on calf rearing and nutrition in China. Journal of Integrative Agriculture, 16 (12), 2805-2814. doi: http://doi.org/10.1016/s2095-3119(17)61767-2

[29] Sun, P., Wang, J. Q., Zhang, H. T. (2010). Effects of Bacillus subtilis natto on performance and immune function of preweaning calves. Journal of Dairy Science, 93 (12), 5851-5855. doi: http://doi.org/10.3168/jds.2010-3263

[30] Shinde, T., Vemuri, R., Shastri, M. D., Perera, A. P., Tristram, S., Stanley, R., Eri, R. (2019). Probiotic Bacillus coagulans MTCC 5856 spores exhibit excellent in-vitro functional efficacy in simulated gastric survival, mucosal adhesion and immunomodulation. Journal of Functional Foods, 52, 100-108. doi: http://doi.org/10.1016/j.jff.2018.10.031

How to cite: Shkromada, O., Dudchenko, Y., Udovenko, Y. (2021). Use of probiotics for formation of microflora of gastrointestinal tract of calves. EUREKA: Health Sciences, 4, 94-100. doi: 10.21303/2504-5679.2021.001951 